\title{
The System of Taxation of Individual Entrepreneurs in the New Realities of Industrialization and Digitalization
}

\author{
Natalia Kosheleva ${ }^{1, *}$, and Anastasia Kosheleva ${ }^{2}$ \\ ${ }^{1}$ Togliatti State University, 445020 Togliatti, Russia \\ ${ }^{2}$ National Research University of the Higher School of Economics, 194100 St. Petersburg, Russia
}

\begin{abstract}
The topic discussed in this article is current today, since the material contained in it is collected taking into account all the latest amendments to the tax code of the Russian Federation and some federal laws. The article can be a reference material for individual entrepreneurs who are faced with the problem of choosing a tax regime, or for those who want to get acquainted with the latest innovations of the tax code. The nuances of individual entrepreneur taxation in 2020-2021 are considered. Comparative analysis of different tax systems of individual entrepreneur is given, and advantages and disadvantages of each of them are revealed. Examples of calculations of the value of tax or contribution for an individual entrepreneur are given
\end{abstract}

\section{Introduction}

Taxes are an integral part and the main source of replenishment of the budget of any state. If you go deeper into terminology, taxes can be defined as mandatory payments that the state charges legal entities and individuals in order to meet public needs. This concept is one of the most important social institutions and implies the performance of functions such as: fiscal; distributive; regulating.

For individual entrepreneurs, it is customary to allocate six tax systems, namely:

- General taxation system;

- Flat agricultural tax;

- Simplified Tax System;

- Single imputed income tax;

- Patent system of taxation;

- Tax on professional income [1].

* Corresponding author: cavva01@mail.ru 


\section{Materials and methods}

There are 5 preferential and 1 general types of tax systems, differing from each other by the tax object, tax base, rate, period and procedure of calculation and, accordingly, payment of tax.

The main difference between preferential tax systems and the general one is that any IE can work under the second without any restrictions. In the case of preferential regimes, it is necessary to comply with a number of requirements imposed by the Russian Federation. Consider each of the systems separately.

An IE working under a general taxation system

This taxation system is valid from the moment of registration of IE by default, if the entrepreneur did not immediately submit an application for transition to a preferential tax system.

Conditions under which IE can only operate under a simplified tax system:

- more than 100 employees in IE;

- foreign organizations;

- income for the first year, quarter, half-year or the first 9 months exceeds 150 million rubles;

- pawnshops; notarial offices; banks; insurance companies; lawyers.

Table 1. List of taxes that IE is obliged to pay when working under the general tax system

\begin{tabular}{|c|c|c|}
\hline Taxes & Term & Interest rate \\
\hline VAT & Monthly up to 25 th & $\begin{array}{l}20 \% \text { in the general case } \\
10 \% \text { - when working with a specific } \\
\text { category of goods }\end{array}$ \\
\hline Personal income tax & $\begin{array}{l}\text { Until July 15th for } \\
\text { January-June }\end{array}$ & $13 \%$ \\
\hline Property tax & $\begin{array}{l}\text { Until October 15th for } \\
\text { July-September }\end{array}$ & $2,2 \%$ \\
\hline $\begin{array}{l}\text { Land and transport } \\
\text { taxes }\end{array}$ & $\begin{array}{l}\text { Until January } 15 \text { for } \\
\text { October-December next } \\
\text { year }\end{array}$ & Land tax from $0.3 \%-1.5 \%$ \\
\hline $\begin{array}{l}\text { Insurance premiums } \\
\text { for themselves }\end{array}$ & $\begin{array}{l}\text { Up to 1st December } \\
\text { next year }\end{array}$ & $\begin{array}{l}\text { a. compulsory pension insurance }-22 \% \text {; } \\
\text { b. compulsory social insurance }-2.9 \% \text {; } \\
\text { c. compulsory health insurance }-5.1 \text { per } \\
\text { cent; } \\
\text { d. compulsory accident insurance from } \\
0.2 \%-8.5 \%\end{array}$ \\
\hline $\begin{array}{l}\text { Employee premiums } \\
\text { and taxes }\end{array}$ & $\begin{array}{l}\text { Until December 1st next } \\
\text { year - land tax }\end{array}$ & $\begin{array}{l}\text { a. compulsory pension insurance }-22 \% \text {; } \\
\text { b. compulsory social insurance }-2.9 \% \text {; } \\
\text { c. compulsory health insurance }-5.1 \text { per } \\
\text { cent; } \\
\text { d. compulsory accident insurance from } \\
0.2 \%-8.5 \% \text {. }\end{array}$ \\
\hline
\end{tabular}

An IE working under a flat agricultural tax

This tax regime is developed for entrepreneurs producing agricultural products. You can switch to this tax regime if:

- the activity of the enterprise is related to crop production, animal husbandry, fish farming, agriculture or forestry;

- at least $70 \%$ of the organization's income should be obtained as a result of the sale of agricultural products;

- not more than 300 workers. 
The significant advantages of this regime include the absence of the need to pay taxes such as property tax and VAT.

The list of taxes mandatory for payment includes: personal income tax for employees; contributions for compulsory health insurance and compulsory pension insurance; the tax itself.

To switch to this mode, you must contact the tax authority at the place of residence.

Table 2. Required reporting

\begin{tabular}{|l|l|}
\hline Type of reporting & Terms \\
\hline Advance payment & Not later than July 25 of this year \\
\hline Rest & No later than March 31 of the following year; \\
\hline Filing a declaration & No later than March 31 of the following year; \\
\hline
\end{tabular}

The interest rate of the CEFIC is $6 \%$ and is charged against the difference between the income and the expenditure of the IE [2].

An IE working under a simplified tax system

Among all tax regimes, it gained the greatest popularity. Largely due to the fact that the working conditions here are the most universal, but more suitable for representatives of small and medium-sized businesses.

Conditions for switching:

- less than 100 workers;

- income less than 150 million;

- type of entrepreneurial activity is included in the list of permitted;

- income for 9 months was less than 112, 5 million rubles;

- no branches.

One of the main advantages of this tax regime is considered an exemption from the entire list of taxes. These include:

- personal income tax;

- property tax;

- VAT (exception - imported goods).

The entrepreneur can switch to a simplified taxation system either at the time of registration of the individual entrepreneurs, or submit an application for an existing enterprise (no later than December 31, the transition will be carried out from next year).

There are 2 types that can be characterized as:

- Income;

- Income - expenses.

Consider both options.

Income

For this system, only the revenue part is taxed. In this case, the interest rate is $6 \%$, but can be changed downwards by decision of the municipality.

Income - Expenses

For this system, the tax base will be the difference between income and expenses. In this case, the interest rate is $15 \%$ [3].

Table 3. List of taxes paid

\begin{tabular}{|l|l|l|}
\hline Tax & Interest rate & Terms \\
\hline $\begin{array}{l}\text { Tax on simplified } \\
\text { tax system }\end{array}$ & Under the "Income" scheme 6\% & Until 30.04 next year \\
\cline { 2 - 2 } & Under Income - Expenses 15\% & \\
& &
\end{tabular}


Table 3. Continued

\begin{tabular}{|c|c|c|}
\hline \multirow{2}{*}{$\begin{array}{l}\text { Contributions for } \\
\text { compulsory } \\
\text { pension insurance }\end{array}$} & 32,488 rub. & Before 31.12.2020 \\
\hline & $\begin{array}{l}+1 \% \text { of the amount by which IE } \\
\text { income exceeded } 300 \text { thousand rubles. }\end{array}$ & \\
\hline $\begin{array}{l}\text { Compulsory } \\
\text { health insurance } \\
\text { premiums }\end{array}$ & 8,426 rub. & Before 01.07.2021 \\
\hline \multicolumn{3}{|l|}{ For IE with working } \\
\hline $\begin{array}{l}\text { Personal income } \\
\text { tax }\end{array}$ & $13 \%$ & $\begin{array}{l}\text { No later than the next day } \\
\text { after payment of salary }\end{array}$ \\
\hline $\begin{array}{l}\text { Mandatory } \\
\text { insurance } \\
\text { premiums for } \\
\text { employees }\end{array}$ & $\begin{array}{l}\text { Compulsory pension insurance } 22 \% \\
\text { Compulsory health insurance } 5.1 \% \\
\text { Compulsory social insurance } 2.9 \% \\
\text { Injuries } 0.2-8.5 \%\end{array}$ & $\begin{array}{l}\text { No later than the } 15 \text { th of the } \\
\text { next quarter }\end{array}$ \\
\hline
\end{tabular}

An IE working under a single imputed income tax

It is believed that the system in question is one of the most convenient, since the amount of taxes paid is independent of income. Unfortunately, since 2021 this system has been abolished.

Nevertheless, in 2020, IP can work on it, suitable for criteria such as:

- IE engaged in road transport must have no more than 20 cars in their fleet;

- IE in trade and services should have no more than 150 square meters occupied by the service room or trading room;

- This mode has been introduced in the region [4].

An IE working under a patent system of taxation

The patent taxation system is applied in the territory of certain constituent entities of the Russian Federation and the interest rate can also vary. The patent is issued for a period of 1 to 12 months.

A IE that meets the following conditions can go:

- no more than 15 employees;

- revenues not more than $60 \mathrm{mln}$ RUB;

- type of activity fits the patent;

- carrying out activities in the specific region where the patent is registered.

If we talk about the tax rate, then we need to take into account the fact that each region establishes its own tax base. In turn, the tax rate will be $6 \%$ [5].

Table 4. Taxes required for PSN payment and due dates

\begin{tabular}{|l|l|}
\hline \multirow{2}{*}{ No need to pay: } & Personal income tax \\
\cline { 2 - 2 } & Personal property tax \\
\cline { 2 - 3 } & VAT \\
\hline You must pay for: & \\
\hline $\begin{array}{l}\text { Compulsory health insurance and } \\
\text { compulsory pension insurance for } \\
\text { individual entrepreneurs }\end{array}$ & Before 31.12.2020 \\
\hline $\begin{array}{l}\text { Compulsory pension insurance with } \\
\text { excess income for }\end{array}$ & Before 01.07.2020 \\
\hline $\begin{array}{l}\text { Mandatory contributions } \\
\text { employees }\end{array}$ & Up to 15th of next month: \\
\hline $\begin{array}{l}\text { Tax on the patent system of taxation } \\
\text { Onder the operation of the patent } 6 \text { months: } \\
\text { One full amount not later than the expiry date of the patent }\end{array}$ \\
\hline & $\begin{array}{l}\text { With the operation of the patent from } 6 \text { to } 12 \text { months: } \\
1 / 3 \text { not later than } 90 \text { days from the patent commencement date } \\
2 / 3 \text { no later than the expiry date of the patent }\end{array}$ \\
\hline
\end{tabular}


An IE working under a tax on professional income

23 regions in the Russian Federation will be able to apply this regime [6].

The transition will be able to:

- citizens who profit from the use of any property or from the independent conduct of activities;

- carries out activities in the region where this regime is introduced;

- IP itself is not a hired worker;

- IP has no employees;

- Carries out the activity listed in Article 4, 6 No. 422-Federal Law of 27.11.2018;

- income not more than RUB $2.4 \mathrm{mln}$.

The interest rate for an individual entrepreneur depends on the type of profit received. If IP, received income from:

- individual, rate $4 \%$;

- IP or legal entity, rate $6 \%$.

Non-binding taxes include:

- personal income tax;

- insurance premiums;

- VAT.

The deadlines for paying tax under the regime will be every 25th of the next month [7].

\section{Results and discussion}

Having carried out a comparative analysis of different tax systems of IP, one can distinguish the advantages and disadvantages of each of them.

General taxation system

Pluses:

- ability to work with large and medium-sized companies as they prefer cooperation with VAT payers. If you work on the general tax system, you must pay this type of tax;

- there are no restrictions on parameters such as:

- Revenue volume;

- Number of employees;

- Size of fixed assets;

- Type of activity.

Minuses:

- a lot of taxes;

- large volume of reporting;

- accounting is required.

Thus, it can be concluded that this regime is not always an advantageous option due to the large number of taxes and reporting, but these disadvantages are compensated by the fact that there are few restrictions on activities [8].

Flat agricultural tax

Pluses:

- low interest rate;

- paying tax twice a year, which is quite convenient in terms of time, especially for individual entrepreneurs associated with the agricultural sector, and therefore with seasonality.

Minuses:

- a narrow range of activities; 
- $\quad$ restrictions on the number of workers and the percentage of earnings from the sale of agricultural products.

Simplified Taxation System

Pluses:

- rather low interest rate;

- the need to submit the declaration only once a year (not later than April 30 of the next year);

- opportunity to fall under the tax vacation program.

Minuses:

- difficulties with correct miscalculations of all possible outcomes and the amount of contributions and choosing a more profitable scheme from the two existing ones;

- a large list of conditions that IE must meet for switching to simplified taxation system

Patent Tax System

Pluses:

- you do not have to pay a number of taxes;

- simplified type of accounting;

- no declaration.

Minuses:

- $\quad$ restrictions on the number of employees and types of entrepreneurial activity;

- limited period of patent use;

- the patent is valid within the region [9].

Professional income tax

Pluses:

- there is no need to submit a declaration and any reports (revenues are recorded in a special mobile application);

- $\quad$ it is not necessary to pay a number of taxes and contributions;

- tax deduction can be obtained at one time;

- interest rates are quite profitable.

Minuses:

- launched in only a few regions of the Russian Federation;

- an individual entrepreneur may not himself be an employee or have employees;

- only activities on the list provided for by the law in Article 4, 6 No. 422-Federal Law from 27.11.2018 may apply this regime;

- $\quad$ income should not exceed $2.4 \mathrm{mln}$.

\section{Conclusions}

Having analyzed information on tax systems for an individual entrepreneur, it can be concluded that before opening a business, an individual must fully familiarize himself with the conditions of each regime, analyze the shortcomings and advantages of each of them. First of all, it is necessary to take into account the type of activity carried out, because many regimes are suitable only for certain types. Then you need to focus on the limits on the income of the enterprise, the volume of retail space, the number of employees and the presence of branches. The last, but important step should be the calculation of the approximate value of tax deductions. This article lists all nuances, interest rates and tax deduction dates [10].

It happens that the type of activity of the entrepreneur fits several regimes, it is important to calculate the approximate amount of tax deductions. Not always a small 
interest rate can indicate the profitability of the regime. Much depends on the object of taxation.

\section{References}

1. Tax Code of the Russian Federation

2. Official website of the Federal Tax Service: Unified agricultural tax, https://www.nalog.ru/

3. Official website of the Federal Tax Service: Simplified tax system, https://www.nalog.ru/

4. Official website of the Federal Tax Service: Unified tax on imputed income, https://www.nalog.ru/

5. Official website of the Federal Tax Service: Patent tax system, https://www.nalog.ru/

6. Federal Law "On Conducting an Experiment to Establish a Special Tax Regime" Professional Income Tax "

7. Official website of the Federal Tax Service: Professional income tax, https://npd.nalog.ru/

8. S. Barulin, Theory and history of taxation, (2018)

9. G. Yu. Kasyanova, Individual entrepreneur: everything about everything, (2020)

10. N. Kosheleva, N. Gorbacheva, O. Evchenko, T. Ivanova, Springer Nature, 817 (2020) 